\title{
Analisis Hasil FTIR Dari Buah Kedondong dan Labu, Ubi Jalar dan Wortel Sebagai Bahan Alternatif Dye Sensitized Solar Cell (DSSC) Dengan Metode Multivariat
}

\author{
Spectra FTIR Analysis of Kedondong and Pumpkin Fruits, Sweet \\ Potato and Carrot for Choosing Dye Sensitized Solar Cell \\ (DSSC) Materials Using Multivariate Method
}

\author{
Engelia Rambu Maramba Meha ${ }^{1}$, Windarjoto ${ }^{1}$, Hery Suyanto ${ }^{1 *}$ \\ ${ }^{1}$ Jurusan Fisika, Fakultas Matematika dan Ilmu Pengetahuan Alam, Universitas Udayana, Kampus Bukit \\ Jimbaran, Badung, Bali, Indonesia 80361 \\ Email: rambumaramba@student.unud.ac.id; windaryoto@unud.ac.id; *hery@unud.ac.id
}

\begin{abstract}
Abstrak - Telah dilakukan penelitian tentang analisis berbagai macam bahan alternatif Dye Sensitized Solar Cell (DSSC) menggunakan Fourier-Transform Infrared Spectroscopy (FTIR) dengan metode Multivariate. Penelitian ini menggunakan kulit buah Manggis dan Naga sebagai sampel pembanding (acuan) dan buah Kedondong dan Labu, serta Ubi Jalar dan Wortel, sebagai sampel bahan alternatif DSSC. Sampel dibuat dalam bentuk serbuk dan dikarakterisasi dengan FTIR. Data spektra FTIR diolah dengan metode Multivariate khususnya algoritma principle component analysis (PCA) dan clustering. Hasil menunjukkan bahwa Ubi jalar dan buah Kedondong memiliki karakteristik yang lebih mendekati karakteristik buah Naga, dibandingkan terhadap buah Manggis dengan selisih kedekatan sebesar 1,6\%. Oleh karena itu Ubi jalar dan buah Kedondong berpotensi dapat digunakan sebagai bahan alternatif Dye Sensitized Solar Cell (DSSC).
\end{abstract}

Kata kunci: DSSC, FTIR, metode Multivariate, PCA, clustering.

\begin{abstract}
Research had been carried out on the analysis of various kinds of material as an alternative material for Dye Sensitized Solar Cells (DSSC) using Fourier-Transform Infrared Spectroscopy (FTIR) with Multivariate method. This study used Mangosteen and dragon fruits as reference samples, Kedondong and Pumpkin fruits as well as Sweet Potatoes and Carrots, as samples of DSSC alternative materials. The sample was made into powder and then was analyzed by FTIR. The FTIR spectra data were processed by the Multivariate method, especially the principle component analysis (PCA) and clustering algorithm. The results showed that both sweet potato and Kedondong fruit had characteristics that were closer to the characteristics of Dragon fruit, compared to Mangosteen fruit with a difference in proximity of $1.6 \%$. Therefore, sweet potato and Kedondong fruit can potentially be used as alternative materials for Dye Sensitized Solar Cell (DSSC).
\end{abstract}

Key words: DSSC, FTIR, Multivariate method, PCA, clustering.

\section{Pendahuluan}

Berdasarkan letak geografis, Indonesia merupakan sebuah negara yang dilewati garis khatulistiwa dan mendapatkan sumber energi matahari yang melimpah dengan intensitas radiasi matahari rata-rata sekitar $4,8 \mathrm{kWh} / \mathrm{m}^{2}$ per hari diseluruh wilayah Indonesia [1]. Pemanfaatan energi matahari dengan pembuatan sel surya saat ini dibuat secara konvensional berbahan dasar logam semikonduktor seperti silikon. Penggunaan bahan silikon ini ternyata memiliki banyak kekurangan diantaranya perlu menggunakan silikon murni, bahan kimia dan harga produksi yang mahal [2]. Untuk mengatasinya, telah dikembangkan sel surya berbasis dye atau yang dikenal dengan dye sensitized solar cell (DSSC). Bahan pokok DSSC adalah menggunakan zat warna (dye) peka cahaya yang diperoleh dari buah-buahan, ubi-ubian yang mengandung antosianin. Zat warna dilapiskan pada titanium dioksida $\left(\mathrm{TiO}_{2}\right)$ untuk menghasilkan listrik. Mekanisme di dalam DSSC yang mana proses absorpsi cahaya dan pemisahan muatan listrik terjadi pada proses yang terpisah. Cahaya diserap oleh zat pewarna dan pemisahan muatan terjadi pada $\mathrm{TiO}_{2}$ yang memiliki celah pita besar. Penggunaan $\mathrm{TiO}_{2}$ relatif murah, banyak dijumpai, inert, tidak beracun dan merupakan bahan yang biokompatibel. Dengan demikian DSSC mempunyai keunggulan, tidak 
memerlukan bahan dengan kemurnian tinggi, hemat biaya produksi dan proses fabrikasi yang mudah serta ramah lingkungan [3]. Dye yang digunakan dalam pembuatan DSSC adalah antosianin karena antosianin mampu menyerap spektrum sinar matahari pada rentang panjang gelombang yang lebar yaitu pada rentang warna biru, biru kehijauan dan hijau muda.

Beberapa penelitian telah dilakukan untuk membuktikan bahwa dye terdapat pada senyawa organik, diantaranya pada penelitian ekstrak Ubi Jalar ungu [4], buah Murbai [5], Kol merah [6], buah Salak [7], kulit buah Naga merah dan Manggis [8,9] yang mana semuanya ini dapat digunakan sebagai bahan DSSC karena mengandung antosianin. Secara umum, kulit buah Naga dan kulit buah Manggis merupakan dua jenis buah yang sudah dan sering digunakan sebagai bahan DSSC. Oleh karena itu pada penelitian ini, kedua buah tersebut digunakan sebagai pembanding atau validator dari empat bahan alternatif lainnya buah Kedondong (spondias dulcis), Wortel (daucus carota subsp), buah Labu (cucurbita moschata), Ubi jalar (ipomoea batatas). Ke enam bahan tersebut diolah menjadi serbuk dan dilakukan pengujian menggunakan Fourier Transfrom Infrared Spectroscopy (FTIR). Sedangkan untuk mengetahui kemiripan kandungan antosianin, empat bahan alternatif (buah Kedondong, buah Labu, Ubi jalar dan Wortel) terhadap dua validatornya (kulit buah Manggis dan kulit buah Naga) perlu dilakukan analisis lebih lanjut menggunakan metode multivariate khususnya dengan algoritma principle component analysis (PCA) dan clustering. PCA digunakan dalam penelitian ini karena dapat digunakan menyederhanakan sejumlah data yang besar dengan cara mengelompokan variabel-variabel yang mempunyai kemiripan sifat penyusun kimianya, sedangkan clustering dapat digunakan untuk mengelompokan sampel-sampel yang berdasarkan kemiripan sifat antar sampel. Sehingga untuk menghemat waktu, bahan dan biaya pengerjaan pembuatan DSSC, maka tujuan dalam penelitian ini yaitu perlu melakukan penyeleksian awal terhadap bahan alternatif yang mempunyai kemiripan terhadap buah yang sudah sering digunakan untuk DSSC yaitu kulit buah Naga dan Manggis.

\section{Landasan Teori}

\subsection{Dye Sensitized Solar Cell (DSSC)}

Cahaya Matahari merupakan sumber energi yang besar dan melimpah. Untuk meningkatkan pemanfaatannya maka perlu dilakukan konversi energi cahaya tersebut menjadi listrik yang salah satunya seperti dilakukan oleh Gratzel [10]. Gratzel menemukan bahwa $\mathrm{TiO}_{2}$ (titanium dioksida) yang dilapisi oleh dye dalam larutan elektrolit dapat menghasilkan arus listrik dengan efisiensi 7,1\%. Solar Cell ini kemudian disebut sebagai Dye Sensitized Solar Cell (DSSC). Peningkatan efisiensi dari DSSC terus dikembangkan diantaranya dengan melakukan penelitian menggunakan bahan organik (alami) seperti buah dan umbi-umbian sebagai bahan dye-sensitizer yang mana merupakan komponen penting dalam DSSC.

Umumnya yang digunakan sebagai dye-sensitized adalah ruthenium kompleks, tetapi karena harganya yang mahal dan mengandung logam berat sehingga merugikan apabila ditinjau dari sudut pandang lingkungan. Oleh kerena itu bahan untuk dye-sensitized digantikan dengan bahan alam yang banyak mengandung antosianin. Antosianin dipilih karena mampu menyerap spektrum sinar matahari yang lebar, yaitu pada rentang warna biru, biru kehijauan dan hijau muda. Selain itu, antosianin sangat sensitif terhadap cahaya dan mampu diuraikan oleh mikroba sehingga tidak membahayakan lingkungan. Antosianin mudah ditemukan di alam dalam bentuk pigmen pada tumbuh-tumbuhan yang berwarna merah, ungu dan biru pada buah ataupun bunga [11].

Berbagai jenis ekstrak tumbuhan telah banyak digunakan sebagai fotosensitizer pada DSSC. Untuk menghemat waktu, bahan dan biaya pengerjaan pembuatan DSSC, maka perlu dilakukan seleksi awal yaitu penyeleksian terhadap bahan yang mempunyai kemiripan terhadap buah yang sudah sering digunakan untuk DSSC yaitu buah Naga merah dan Manggis $[8,9]$. Di dalam penelitian ini kedua buah ini digunakan sebagai pembanding atau validator terhadap 4 bahan alternatif lainnya, yaitu buah Kedondong, buah Labu, Wortel dan Ubi Jalar.

\subsection{Spektroskopi Fourier Transform Infrared Spectroscopy (FTIR)}

Spektroskopi FTIR adalah teknik pengukuran untuk mengumpulkan spektra inframerah. Pada spektroskopi FTIR, jika suatu frekuensi tertentu dari radiasi inframerah dilewatkan pada sampel suatu senyawa organik maka akan terjadi penyerapan frekuensi oleh senyawa tersebut. Serapan yang terjadi pada spektroskopi FTIR menghasilkan spektra berupa grafik pada sumbu vertikal yang menunjukkan transmitansi (\%) yang bervariasi pada setiap frekuensi radiasi inframerah. Satuan frekuensi yang 
digunakan pada sumbu horizontal (absis) dinyatakan dalam bilangan gelombang $\left(\mathrm{cm}^{-1}\right)$, yang menunjukan adanya gugus fungsi tertentu $[12,13]$.

\subsection{Metode multivariate}

Metode multivariate atau yang sering dikenal juga dengan Chemometrics Methods adalah sebuah metode matematika dan statistika untuk analisis data secara optimum. Metode multivarite juga dapat digunakan sebagai desain penelitian untuk mendapatkan informasi yang berharga dari sebuah penelitian yang telah dilakukan. Analisis ini dapat juga digunakan untuk analisis hasil karakterisasi dari instrumen analitik yang merupakan suatu data yang kompleks [14]. Metode multivariate terdiri dari dua klasifikasi yaitu teknik dependence (tergantung) dan teknik interdependence (saling ketergantungan). Teknik dependence adalah suatu metode analisis multivariate, dimana kumpulan variabel yang diidentifikasi sebagai variabel dependence, dapat diprediksi dan dijelaskan oleh variabel lain yang merupakan variabel independence. Analisis dependence berfungsi untuk menjelaskan dan memprediksi variabel terikat (dependence) dengan menggunakan dua atau lebih variabel bebas (independence). Analisis yang termasuk dalam klasifikasi dependence adalah analisis Regresi, Varians, Korelasi Kanonik, dan Diskriminan. Sedangkan teknik interdependence adalah analisis multivariate yang melibatkan analisis secara serentak dari semua variabel dalam satu kumpulan/kelompok, tanpa membedakan antara variabel terikat ataupun variabel bebas. Teknik analisis interdependence berguna dalam memberikan makna terhadap sekelompok variabel atau membuat kelompok-kelompok secara bersama-sama. Beberapa analisis yang merupakan bagian dari klasifikasi ini adalah principle component analysis (PCA), Clustering, dan Log-Linier) [15].

\section{Metode Penelitian}

Pada penelitian ini digunakan dua buah sebagai validator yaitu kulit buah Naga dan kulit buah Manggis $[8,9]$ dan empat bahan alternatif DSSC lainnya (buah Kedondong, buah Labu, Ubi Jalar, dan Wortel). Ke enam bahan ini dipotong-potong dan dikeringkan pada suhu ruangan selama 3 minggu yang kemudian dibuat menjadi serbuk. Sampel serbuk selanjutnya dianalisis dengan FTIR (Shimadzu IRPrestige-21). Perbandingan antara sampel serbuk dan $\mathrm{KBr}$ adalah 0,007 g dan 0,003 g. Hasil pengukuran FTIR dari ke enam sampel diolah dengan Microsoft Excel sedemikian rupa sehingga diperoleh data nilai transmitansi $(\%)$ dan bilangan gelombang $\left(\mathrm{cm}^{-1}\right)$. Ini dilakukan untuk keperluan analisis multivariate interdependence (PCA dan Clustering) yang mana perlu dilakukan transpose data antara transmitansi dan bilangan gelombang. Langkah berikutnya, data spektra gabungan diproses dengan program The Unscrambler dan dilakukan analisis dengan algoritma PCA dan clustering sehingga diperoleh hasil berupa gambar score plot dan clustering.

\section{Hasil Dan Pembahasan}

\subsection{Hasil Fourier Transform InfraRed (FTIR)}

Sampel dari buah Kedondong, Wortel, Ubi Jalar, buah Labu, kulit buah Manggis dan kulit buah Naga dianalisis dengan FTIR. Perbandingan sampel serbuk dan $\mathrm{KBr}$ adalah 0,007 g dan 0,003 g. Hasil karakterisasi dengan FTIR dari keenam sampel seperti ditunjukkan pada Gambar 1.

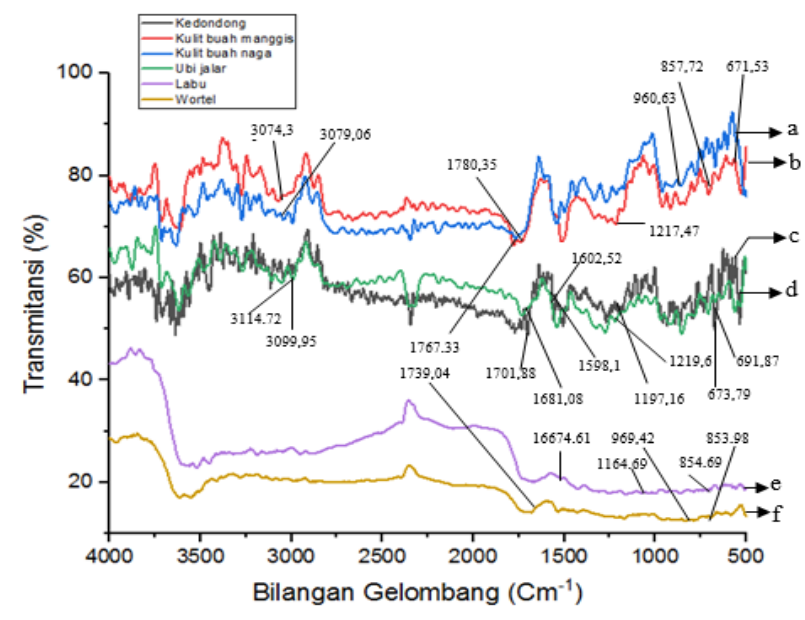

Gambar 1. Spektra FTIR sampel serbuk dari 6 jenis bahan: (a) kulit buah Naga, (b) kulit buah Manggis (c) buah Kedondong, (d) Ubi Jalar, (e) Labu, dan (f) Wortel. 
Dari spektra pada Gambar 1 tampak bahwa serbuk dari buah Kedondong, kulit buah Manggis, kulit buah Naga dan Ubi Jalar mempunyai kemiripan pola spektra, kurva transmitansinya berada di atas 50\%. Sementara itu, serbuk Wortel dan buah Labu mempunyai kemiripan pola yang lain, kurva transmitansinya berada di bawah $50 \%$. Ke enam spektra tersebut mempunyai nilai transmitansi yang berbeda-beda dan masih dibawah $100 \%$. Semakin kecil nilai transmitansi maka radiasi inframerah yang diserap oleh sampel atau senyawa akan semakin besar.

Selanjutnya, data spektra transmitansi masing-masing sampel pada Gambar 1 dianalisis kandungan antosianinnya, yaitu dengan memperhatikan puncak transmitansi dari gugus fungsi aromatiknya. Hasilnya seperti ditunjukkan pada Tabel 1.

Tabel 1. Gugus fungsi 6 bahan serbuk pada pengujian FTIR.

\begin{tabular}{|c|c|c|c|c|c|c|c|c|c|c|c|c|c|}
\hline \multirow{3}{*}{$\begin{array}{l}\text { Refrensi } \\
\text { Bilangan } \\
\text { gelombang } \\
(\text { Bil Gel.) } \\
\left(\mathrm{cm}^{-1}\right) *\end{array}$} & \multicolumn{12}{|c|}{ Transmitans (T) $(\%)$} & \multirow{3}{*}{$\begin{array}{l}\text { Gugus } \\
\text { Fungsi }\end{array}$} \\
\hline & \multicolumn{2}{|c|}{ Kedondong } & \multicolumn{2}{|c|}{ Kulit Manggis } & \multicolumn{2}{|c|}{ Kulit Naga } & \multicolumn{2}{|c|}{ Labu } & \multicolumn{2}{|c|}{ Wortel } & \multicolumn{2}{|c|}{ Ubi Jalar } & \\
\hline & $\begin{array}{c}\text { Bil.gel } \\
\left(\mathrm{cm}^{-1}\right)\end{array}$ & $\begin{array}{c}\mathrm{T} \\
(\%)\end{array}$ & $\begin{array}{l}\text { Bil gel } \\
\left(\mathrm{cm}^{-1}\right)\end{array}$ & $\begin{array}{c}\mathrm{T} \\
(\%)\end{array}$ & $\begin{array}{l}\text { Bil gel } \\
\left(\mathrm{cm}^{-1}\right)\end{array}$ & $\begin{array}{c}\mathrm{T} \\
(\%)\end{array}$ & $\begin{array}{c}\text { Bil gel } \\
\left(\mathrm{cm}^{-1}\right)\end{array}$ & $\begin{array}{c}\mathrm{T} \\
(\%)\end{array}$ & $\begin{array}{l}\text { Bil gel } \\
\left(\mathrm{cm}^{-1}\right)\end{array}$ & $\begin{array}{c}\mathrm{T} \\
(\%)\end{array}$ & $\begin{array}{c}\text { Bil gel } \\
\left(\mathrm{cm}^{-1}\right)\end{array}$ & $\begin{array}{c}\mathrm{T} \\
(\%)\end{array}$ & \\
\hline $3130-3070$ & 3114,72 & 57,94 & 3074,32 & 74,99 & 3079,06 & 72,14 & - & - & - & - & 3099,95 & 20,42 & $\begin{array}{l}\text { aromatic } \\
\text { C-H } \\
\text { stretch }\end{array}$ \\
\hline $2000-1660$ & 1701,88 & 49,04 & 1780,25 & 66,23 & 1767,33 & 67,73 & 1674,61 & 20,19 & 1739,04 & 52,73 & 1681,08 & 14,16 & $\mathrm{C}=\mathrm{C}-\mathrm{C}^{\mathrm{b}}$ \\
\hline $1615-1580$ & 1602,52 & 58,3 & - & - & - & - & - & - & - & - & 1598,12 & 56,45 & $\mathrm{C}=\mathrm{C}-\mathrm{C}^{\mathrm{a}}$ \\
\hline $1510-1450$ & 1507,05 & 50,44 & 1510,92 & 67,08 & 1496,3 & 72,79 & - & - & - & - & 1498,65 & 53,56 & $\mathrm{C}=\mathrm{C}-\mathrm{C}^{\mathrm{a}}$ \\
\hline $1225-950$ & 1197,16 & 52,94 & 1217,47 & 70,74 & 960,63 & 77,07 & 1164,69 & 17,5 & 969,42 & 52,08 & 1219,6 & 51,4 & $\begin{array}{l}\mathrm{C}-\mathrm{H} \\
\text { (aromatic } \\
\mathrm{C}-\mathrm{H} \text { in- } \\
\text { plane } \\
\text { bend) }\end{array}$ \\
\hline $900-670$ & 673,79 & 50,45 & 857,72 & 74,39 & 671,53 & 81,98 & 854,69 & 17,84 & 853,98 & 49,12 & 691,87 & 13,18 & $\begin{array}{l}\text { Aromatic } \\
\text { C-H out- } \\
\text { of-plane } \\
\text { bend }\end{array}$ \\
\hline
\end{tabular}

*ref [16], $\left({ }^{\mathrm{a}}=\right.$ aromatic ring stretch $)$, and $\left({ }^{\mathrm{b}}=\right.$ aromatic combination bands).

Pada Tabel 1 dapat dilihat bahwa antosianin pada ke enam bahan berada pada rentang daerah bilangan gelombang aromatiknya, dengan nilai transmitansi yang berbeda-beda. Karena perbedaan bilangan gelombang dan intensitas puncak transmitansi ini menyebabkan kesulitan untuk mengetahui bahan mana yang mempunyai kemiripan dengan buah pembanding atau validatornya. Untuk itu perlu dilakukan analisis lanjutan dengan metode multivariate interdependence (PCA dan clustering) [17].

\subsection{Hasil PCA dan clustering.}

Untuk mengetahui kamiripan kandungan antosianin empat bahan alternatif untuk DSSC (buah Kedondong, Ubi Jalar, Wortel dan buah Labu) terhadap dua buah validator (kulit buah Manggis dan kulit buah Naga) maka perlu dilakukan analisis lebih lanjut. Metode yang digunakan untuk analisis ini adalah menggunakan metode multivariate interdependence khususnya dengan algoritma PCA dan clustering. Hasil analisisnya seperti ditunjukkan pada Gambar 2 dan 3.

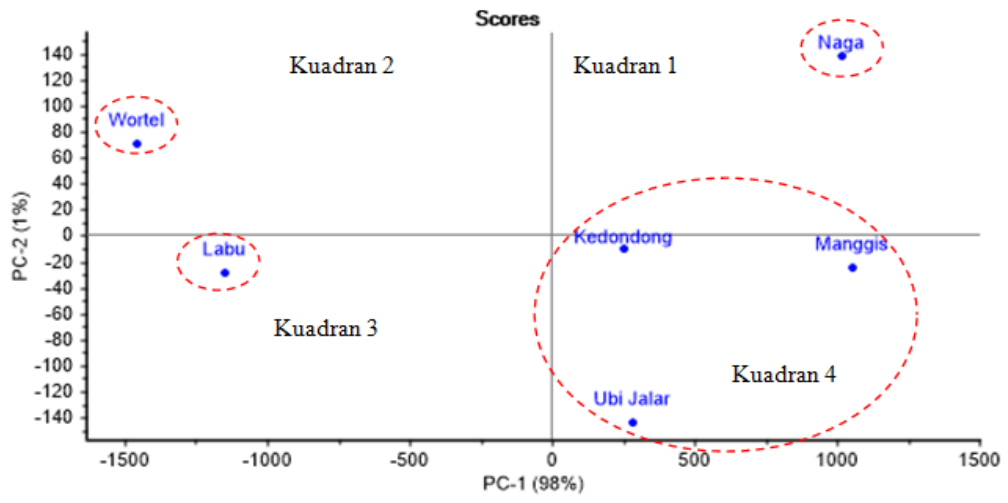

Gambar 2. PCA pada sampel serbuk 6 bahan dengan FTIR. 
Gambar 2 menunjukkan hasil score plot dari 6 jenis bahan yang mana tersebar pada kuadran yang berbeda. Kuadran 1, 2 dan 3 masing-masing ditempati kulit buah Naga, Wortel dan buah Labu. Sedangkan buah Kedondong, kulit buah Manggis dan Ubi Jalar berada dalam satu kuadran yaitu kuadran 4. Nilai PC pada sampel serbuk dari 6 jenis bahan ini mempunyai nilai PC-1 yaitu 98\% dan PC-2 sebesar 1\%. Total dari kedua nilai PC ini 99\%, ini diartikan bahwa nilai PC-1 dan PC-2 mampu menjelaskan 99\% dari variasi data secara keseluruhan. Hasil penjumlahan total variasi dengan persentase $99 \%$ dapat dikatakan baik untuk membangun sebuah pemodelan dalam analisis PCA. Hal ini sesuai dengan penelitian yang dilakukan oleh Wati (2018) yang menyatakan jika jumlah varian dari PC-1 dan PC-2 lebih besar dari 70\%, maka score plot akan memperlihatkan visualisasi dimensi yang baik [18]. Dengan demikian tiga bahan yang berbeda dalam kuadran yang sama ini menunjukkan adanya kemiripan dengan keakurasian yang cukup tinggi. Untuk melihat kemiripan tersebut perlu dilihat nilai koordinat PC untuk setiap sampel yang hasilnya seperti pada Tabel 2 .

Tabel 2. Nilai koordinat PC-1 dan PC-2 untuk sampel serbuk 6 jenis bahan dengan pengujian FTIR.

\begin{tabular}{lcc}
\hline \multicolumn{1}{c}{ Sampel } & PC-1 & PC-2 \\
\hline Kedondong & 253,2841 & $-10,3043$ \\
Ubi Jalar & 281,9857 & $-144,445$ \\
Manggis & 1056,1990 & $-24,9276$ \\
Naga & 1014,8150 & 137,6206 \\
Labu & $-1150,0680$ & $-28,5684$ \\
Wortel & $-1456,2180$ & 70,6258 \\
\hline
\end{tabular}

Proyeksi titik koordinat pada Tabel 2 dapat menunjukkan karakteristik dari setiap sampel. Kemiripan sifat yang dimiliki setiap sampel dapat terlihat dari jarak koordinat antar sampel. Jarak ini menunjukkan derajat kesamaan yang dimiliki tiap sampel. Semakin dekat jaraknya, maka semakin banyak kesamaan yang dimilikinya [15]. Berdasarkan Gambar 2, terlihat bahwa ketiga bahan (buah Kedondong, kulit buah Manggis dan Ubi Jalar) berada dalam satu kuadran 4, akan tetapi setelah di proyeksikan ke koordinat PC terdapat perbedaan dan terpisah menjadi dua kelompok yaitu kelompok buah Kedondong dan Ubi Jalar dan kelompok kulit buah Manggis dan kulit buah Naga. Hasil ini didukung oleh hasil clustering pada Gambar 3.

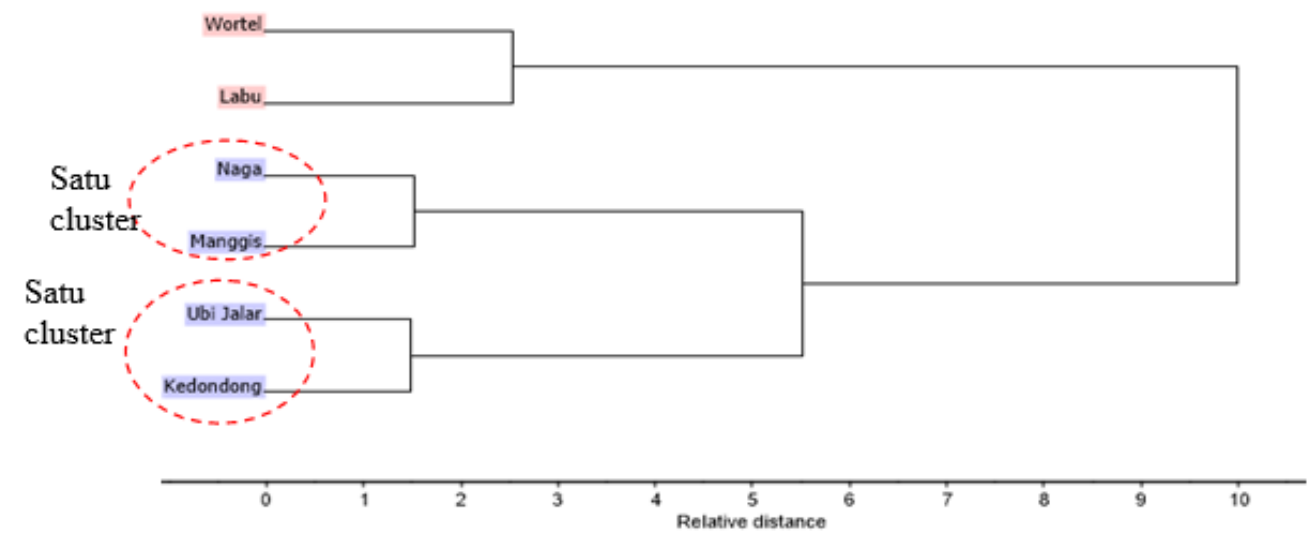

Gambar 3. Hasil clustering sampel serbuk dari 6 jenis bahan.

Analisis clustering dapat lebih jelas memperlihatkan pengelompokkan sampel serbuk dari 6 jenis bahan yang berdasarkan kemiripan sifat antar sampel. Suatu sampel dapat terkelompokkan menjadi satu cluster yang sama melalui nilai kedekatan (similiarity). Oleh karena itu analisis cluster ini dapat dijadikan uji kemiripan dan klasifikasi sampel serbuk dari 6 jenis bahan. Gambar 3 menunjukkan bahwa Ubi Jalar dan buah Kedondong berada pada satu cluster dengan koefisien Euclidean (relative distance) sebesar 1,5. Demikian juga kulit buah Naga dan kulit buah Manggis berada pada satu cluster dengan nilai koefisien Euclidean sebesar 1,5. Sehingga kedua bahan ini (Ubi Jalar dan buah Kedondong) memiliki kemiripan yang tinggi dengan validatornya (kulit buah Naga dan kulit buah Manggis) dan dapat dijadikan sebagai salah satu nominasi bahan alternatif untuk DSSC. Untuk menentukan lebih teliti apakah buah Kedondong atau Ubi Jalar yang mempunyai kedekatan terhadap validatornya, maka perlu dihitung jarak 
Euclidean antar sampel dengan metode Hierarchical Average -linkage [15] dan berdasarkan data pada Tabel 2, maka didapat jarak antar sampel seperti pada Tabel 3.

Tabel 3. Jarak Euclidean antar sampel: $A_{1}=$ Kedondong, $A_{2}=$ Ubi Jalar, $A_{3}=$ Manggis, $A_{4}=$ Naga.

\begin{tabular}{lllll}
\hline & $\mathrm{A}_{1}$ & $\mathrm{~A}_{2}$ & $\mathrm{~A}_{3}$ & $\mathrm{~A}_{4}$ \\
\hline $\mathrm{A}_{1}$ & 0 & 9409 & 322443 & 300906 \\
$\mathrm{~A}_{2}$ & 9409 & 0 & 306845 & 308300 \\
$\mathrm{~A}_{3}$ & 322443 & 306845 & 0 & 14067 \\
$\mathrm{~A}_{4}$ & 300906 & 308300 & 14067 & 0 \\
\hline
\end{tabular}

Pada Tabel 3 menunjukkan bahwa jarak Euclidean terdekat terjadi pada sampel buah Kedondong $\left(\mathrm{A}_{1}\right)$ dan Ubi Jalar $\left(\mathrm{A}_{2}\right)$ yang berarti $\mathrm{A}_{1}$ dan $\mathrm{A}_{2}$ berada pada satu cluster dengan jarak Euclidean sebesar 9409. Hal ini sesuai dengan hasil clustering Gambar 3. Berdasarkan Gambar 3, buah Kedondong dan Ubi Jalar berada satu cluster dengan kedua validatornya (kulit buah Manggis dan kulit buah Naga), akan tetapi belum terlihat jelas kedekatannya atau kemiripan sifatnya. Untuk itu, selanjutnya cluster sampel buah Kedondong dan Ubi Jalar $\left(\mathrm{A}_{1,2}\right)$ dicari kedekatan karakteristiknya terhadap kedua validatornya yaitu (kulit buah Manggis, $\mathrm{A}_{3}$ ) dan (kulit buah Naga, $\mathrm{A}_{4}$ ) dengan menggunakan metode Hierarchical Average linkage [15], hasilnya seperti pada Tabel 4. Berdasarkan data pada Tabel 4, bahwa kedua buah sampel alternatif DSSC ini lebih mendekati karakteristiknya ke kulit buah Naga $\left(\mathrm{A}_{1,2}\right)_{4}$ yaitu 49,2 \% dibandingkan ke kulit buah Manggis $\left(\mathrm{A}_{1}, 2\right)_{3}$ yaitu 50,8 \% yang mana dengan selisih sebesar 1,6\%.

Tabel 4. Jarak Hierarchical Average-linkage (HAL) antara cluster Kedondong-Ubi Jalar terhadap buah Manggis $\left(\mathrm{A}_{1,2}\right)_{3}$ dan antara cluster Kedondong-Ubi Jalar terhadap Naga $\left(\mathrm{A}_{1}, 2\right)_{4}[15]$.

\begin{tabular}{ccc}
\hline Cluster & Jarak HAL & $\%$ \\
\hline$\left(\mathrm{A}_{1,2}\right)_{3}$ & 314644,2 & 50,8 \\
$\left(\mathrm{~A}_{1,2}\right)_{4}$ & 304602,7 & 49,2 \\
& Selisih & 1,6 \\
\hline
\end{tabular}

\section{Kesimpulan}

Dari hasil penelitian ini dapat disimpulkan, dengan menggunakan Teknik multivariate interdependence dengan principle component analysis (PCA) dan clustering diperoleh bahwa buah Kedondong dan Ubi Jalar mempunyai kemiripan sifat terhadap buah Naga dibandingkan terhadap buah Manggis dengan selisih kedekatan sebesar 1,6\%. Oleh karena itu buah Kedondong ataupun Ubi Jalar dapat dijadikan sebagai bahan alternatif untuk bahan dye sensitized solar cell (DSSC).

\section{Ucapan Terima Kasih}

Terima kasih kepada Laboratorium Bersama FMIPA Universitas Udayana atas dukungan dan fasilitas yang diberikan dalam pelaksanaan Penelitian Publikasi ilmiah ini.

\section{Pustaka}

[1] E. S. Tussniari, Ekstrak Antosianin Daging Buah Salak (Salacca Zallacca) untuk Dye Sensitized Solar Cell (DSSC), Skripsi, Program Studi Fisika, Fakultas Matematika dan Ilmu Pengetahuan Alam Universitas Udayana, 2018.

[2] Okti Mulyani, Astuti, Sintesis Sel Surya Tersensitisasi Pewarna (SSTP) Ekstrak Antosianin Buah Delima (Punica Granatum) dengan Metode Sol-Gel-Spin Coating, Jurnal Fisika Unand, Vol.3 No.2, 2014

[3] E. S. Prihandhika, Aplikasi Carbon Nanotube Berbasis Tempurung Kelapa Sebagai Counter Elektrode Panel Surya Tipe DSSC, Skripsi, UIN Sunan Kalijaga, 2018.

[4] Ai Mahmudatussa'adah, D. Firdiaz, N. Andarwulan, F. Kusnandar, Karakteristik Warna dan Aktivitas Antioksidan Antosianin Ubi Jalar Ungu, J.Teknol dan Industri Pangan, Vol. 25 No.2, 2014.

[5] A. N. Azmi, Yunianta, Ekstraksi Antosianin dari Buah Murbei (Morus Alba L.) Metode Microwave Assisted Extraction (Kajian Waktu Ekstraksi dan Rasio Bahan: Pelarut), Jurnal Pangan dan Agroindustri, Vol.3 No.3, 2015, pp. 835-846. 
[6] Ferri Rusady Saputra, Suryasatriya Trihandaru, Adita Sutresno, Identifikasi pH Larutan Antosianin Kol Merah (Brassica Oleracea Var.) terhadap Kinerja Prototipe Dye Sensitized Solar Cell (DSSC), Jurnal Fisika dan Aplikasinya, Vol. 10 No.2, 2014.

[7] Nyoman Wendri, Putu Ekayani Sri Tussniari, Hery Suyanto, Karakterisasi Buah Salak Sebagai Bahan Dye Sensitized Solar Cell (DSSC), Buletin Fisika, Vol.20 No.2, 2019, pp.22-30.

[8] Sri Karina Pinem, Nurdin Siregar, 2018, Pengaruh Waktu Tahan Klasinasi Film Tipis ZNO terhadap Efisiensi DSSC (Dye Sensitized Solar Cell) yang Menggunakan Dye dari Buah Naga Merah, Jurnal Einstein, Vol.5 (3), 2017, pp. 1-7.

[9] Anna Maulina, Hardeli, Bahrizal, Preparasi Dye Sensitized Solar Cell Menggunakan Ekstrak Antosianin Kulit Buah Manggis (Garcinia Mangostana L.), Jurnal Saintek, Vol.VI No.2, 2014, pp.156-167.

[10] M. Gratzel, Dye-Sensitized Solar Cells, Journal of Photochemistry and Photobiology, Vol.4, 2003, pp.145-153.

[11] Joko Suryadi, Gunawan, Abdul Haris, Pembuatan dan Penentuan Nilai Efisiensi Sel Surya Berwarna Tersensitisasi dengan Senyawa Antosianin dari Buah Manggis (Garcinia mangostana L.) Sebagai Pewarna Pensensitisasi, Jurnal Kimia Sains dan Aplikasi, Vol.13 (3), 2010, pp.88-94.

[12] Ayu Anisa Damayanti, Ni Luh Putu Trisnawati, Hery Suyanto, Identifikasi Bilangan Gelombang Daun Sirih (Paper sp.) Menggunakan Metode Spektroskopi Fourier Transform Infrared (FTIR) dan Principal Component Analysis (PCA), Buletin Fisika, Vol.22 No.2, 2021, pp.60-66.

[13] Ayu Anisa Damayanti, Ni Luh Putu Trisnawati, Hery Suyanto, Wavelength Identification of Red Betel Leaf (Piper Crocatum), Green Betel Leaf (Piper Betle L.) and Black Betel Leaf (Piper Betle V.) Using Ultraviolet-Visible (UV-Vis) Spectroscopy Method Coupled with Principal Component Analysis (PCA), Proceedings of SPIE, 11789, 2021, pp.117890K, https://doi.org/10.1117/12.2589414

[14] S. Roussel, J. S. Preys, Lallemand, Multivariate Data Analysis Chemometrics, Analytical for The Food Industry, Claipers France, $8^{\text {th }}$ Edition, Vol.301, 2014.

[15] J. N. Miller, J. C. Miller, Statistic and Chemometrics for Analytical Chemistry, $6^{\text {th }}$ Edition, Ashford Colour Press Ltd, Gosport UK, 2010, pp.221-248.

[16] John Coates, Interpretation of Infrared Spectra, A Practical Approach, Encyclopedia of Analytical Chemistry, R.A Meyers (Ed.) John Wiley \& Sons Ltd, 2000.

[17] N. L. P. Trisnawati, Aprilion Krisandi, Iga Widagda, Iryanti Suprihatin, Hery Suyanto, A Comparation of Different Strategies in Principle Component Analysis (PCA) Algorithm for Clustering Human Tooth Surface using Laser-Induced Breakdown Spectroscopy (LIBS), Journal of Physics: $\quad$ Conference Series, 1572, 2020, 012002. https://iopscience.iop.org/article/10.1088/1742-6596/1572/1/012002

[18] D. Citrasari, Penentuan Adulterasi Daging Babi Pada Nugget Ayam Menggunakan NIR dan Kemimetrik, Skripsi, Fakultas Farmasi Universitas Jember, 2015. 